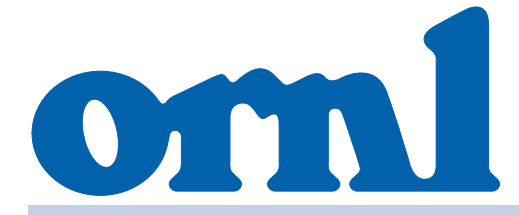

OAK RIDGE NATIONAL LABORATORY

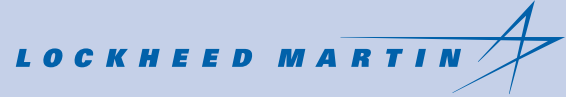

MANAGED AND OPERATED BY

LOCKHEED MARTIN ENERGY RESEARCH CORPORATION FOR THE UNITED STATES

DEPARTMENT OF ENERGY

\section{Life Cycle Costs for the Domestic Reactor-Based Plutonium Disposition Option}

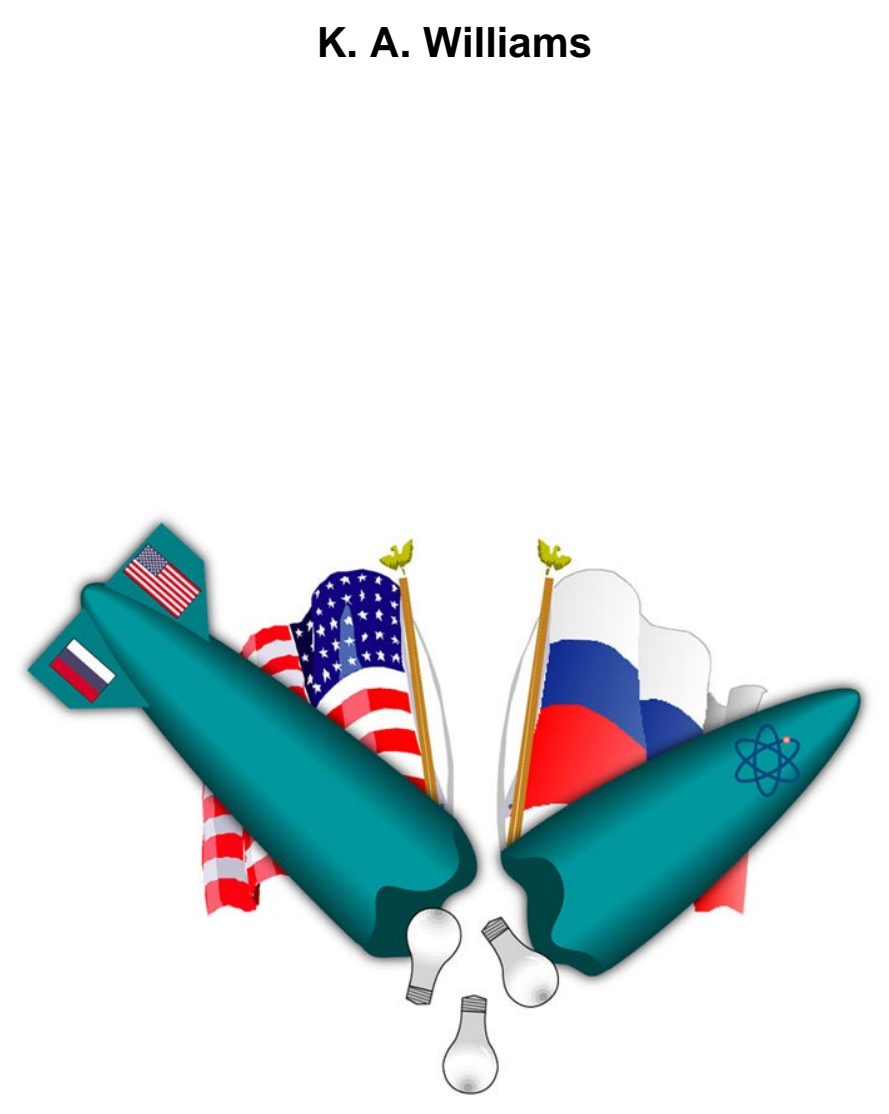

Fissile Materials Disposition Program http://www.ornl.gov/fmdp 
This report has been reproduced from the best available copy.

Reports are available to the public from the following source.

National Technical Information Service

5285 Port Royal Road

Springfield, VA 22161

Telephone 703-605-6000 (1-800-553-6847)

TDD 703-487-4639

Fax 703-605-6900

E-mail orders@ntis.fedworld.gov

Web site http://www.ntis.gov/ordering.htm

Reports are available to U.S. Department of Energy (DOE) employees, DOE contractors, Energy Technology Data Exchange (ETDE) representatives, and International Nuclear Information System (INIS) representatives from the following source.

Office of Scientific and Technical Information

P.O. Box 62

Oak Ridge, TN 37831

Telephone 423-576-8401

Fax 423-576-5728

E-mail reports@adonis.osti.gov

Web site http://www.osti.gov/products/sources.html

Reports produced after January 1, 1996, are generally available via the DOE Information Bridge.

Web site http://www.doe.gov/bridge

This report was prepared as an account of work sponsored by an agency of the United States Government. Neither the United States Government nor any agency thereof, nor any of their employees, makes any warranty, express or implied, or assumes any legal liability or responsibility for the accuracy, completeness, or usefulness of any information, apparatus, product, or process disclosed, or represents that its use would not infringe privately owned rights. Reference herein to any specific commercial product, process, or service by trade name, trademark, manufacturer, or otherwise, does not necessarily constitute or imply its endorsement, recommendation, or favoring by the United States Government or any agency thereof. The views and opinions of authors expressed herein do not necessarily state or reflect those of the United States Government or any agency thereof. 
ORNL/TM-1999-257

Engineering Technology Division

\title{
LIFE CYCLE COSTS FOR THE DOMESTIC REACTOR-BASED PLUTONIUM DISPOSITION OPTION
}

\author{
K. A. Williams
}

Date Published: October 1999

\author{
Prepared by the \\ OAK RIDGE NATIONAL LABORATORY \\ Oak Ridge, Tennessee 37831 \\ managed by \\ LOCKHEED MARTIN ENERGY RESEARCH CORP. \\ for the \\ U.S. DEPARTMENT OF ENERGY \\ under contract DE-AC05-96OR22464
}


Page Intentionally Blank 


\section{CONTENTS}

Page

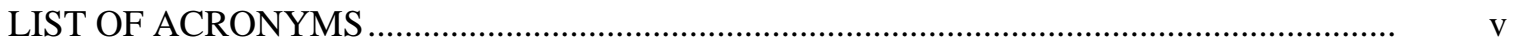

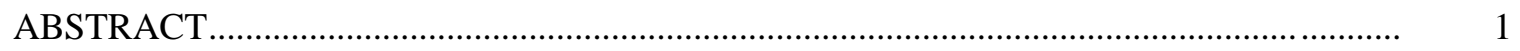

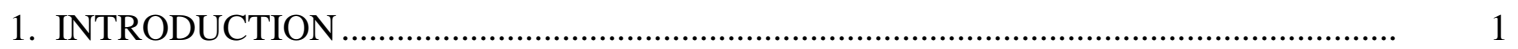

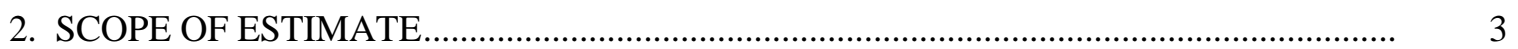

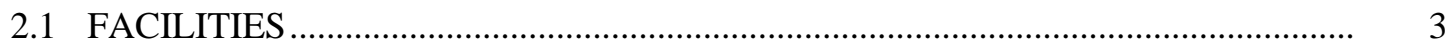

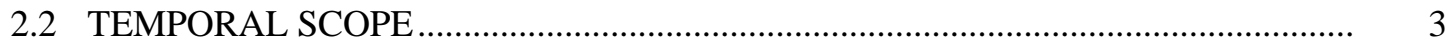

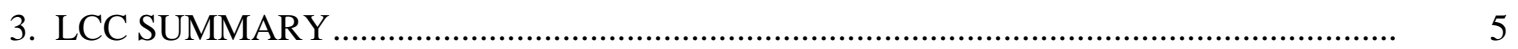

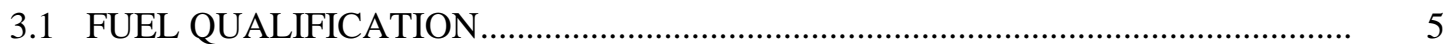

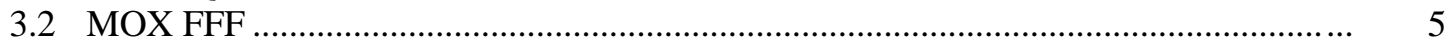

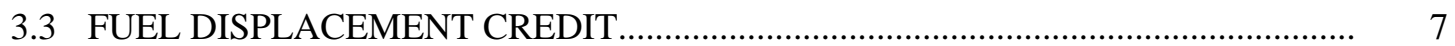

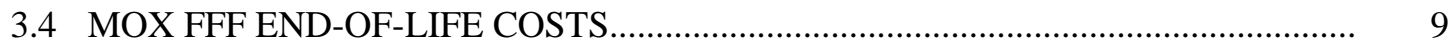

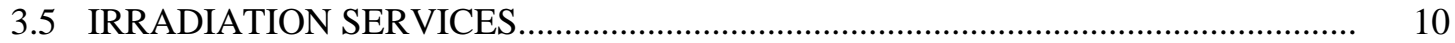

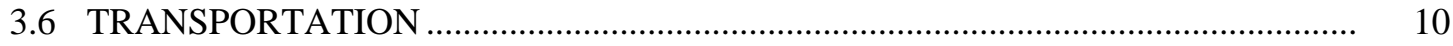

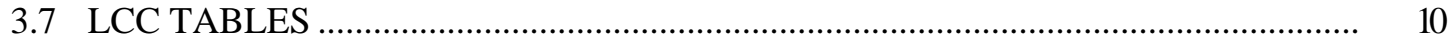

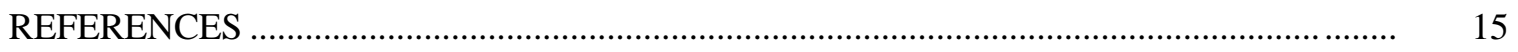


Page Intentionally Blank 


\section{LIST OF ACRONYMS}

$\begin{array}{ll}\text { ATR } & \text { Advanced Test Reactor (at INEEL) } \\ \text { CDR } & \text { conceptual design report } \\ \text { DCS } & \text { Duke/COGEMA/Stone \& Webster, LLC (contractor) } \\ \text { DOE } & \text { U.S. Department of Energy } \\ \text { DP } & \text { Defense Programs (DOE) } \\ \text { DO-CDR } & \text { Design-Only Conceptual Design Report } \\ \text { DUF } 6 & \text { depleted uranium hexafluoride } \\ \text { DUO } & \text { depleted uranium dioxide } \\ \text { EIS } & \text { environmental impact statement } \\ \text { EOL } & \text { end-of-life } \\ \text { F-D } & \text { Fluor-Daniel Group (architect-engineer) } \\ \text { FFF } & \text { fuel fabrication facility } \\ \text { FMDP } & \text { Fissile Materials Disposition Program (MD) } \\ \text { FY } & \text { fiscal year } \\ \text { GOCO } & \text { government-owned, contractor-operated } \\ \text { GFM } & \text { government-furnished material } \\ \text { GFS } & \text { government- furnished service } \\ \text { INEEL } & \text { Idaho National Energy and Environmental Laboratory } \\ \text { IGE } & \text { independent government estimate } \\ \text { LEU } & \text { low-enriched uranium } \\ \text { LANL } & \text { Los Alamos National Laboratory } \\ \text { LCC } & \text { life cycle cost } \\ \text { LWR } & \text { light-water reactor } \\ \text { MOX } & \text { mixed oxide } \\ \text { MOX FFF } & \text { MOX fuel fabrication facility } \\ \text { MT } & \text { metric ton } \\ \text { MTHM } & \text { metric ton of heavy metal (U + Pu) } \\ \text { NRC } & \text { Nuclear Regulatory Commission } \\ \text { NEPA } & \text { National Environmental Policy Act } \\ \text { ORNL } & \text { Oak Ridge National Laboratory } \\ \text { OPC } & \text { operations-funded costs } \\ \text { PORTS } & \text { Portsmouth Gaseous Diffusion Plant } \\ \text { PDCF } & \text { Pit Disassembly and Conversion Facility } \\ \text { PWR } & \text { pressurized-water reactor } \\ \text { PIE } & \text { postirradiation examination } \\ \text { PSAR } & \text { Preliminary Safety Analysis Report } \\ \text { ROD } & \text { Record of Decision } \\ \text { R\&D } & \text { research and development } \\ \text { RASR } & \text { Reactor Alternative Summary Report } \\ \text { RW } & \text { DOE Office of Civilian Radioactive Waste Management } \\ \text { SRS } & \text { Savannah River Site } \\ \text { SST } & \text { safe, secure trailer } \\ \text { SWU } & \text { separative work unit (measure of uranium enrichment) } \\ \text { TA } & \text { technical area (at LANL) } \\ \text { TEC } & \text { total estimated cost (line-item) } \\ \text { TPC } & \text { total project cost (OPC + TEC) } \\ \text { TSR } & \text { technical summary report } \\ \text { UE } & \text { uranium enrichment } \\ \text { YM } & \text { Yucca Mountain } \\ \text { \$M } & \end{array}$


Page Intentionally Blank 


\title{
LIFE CYCLE COSTS FOR THE DOMESTIC REACTOR-BASED PLUTONIUM DISPOSITION OPTION
}

\author{
K. A. Williams
}

\begin{abstract}
Projected constant dollar life cycle cost (LCC) estimates are presented for the domestic reactor-based plutonium disposition program being managed by the U.S. Department of Energy Office of Fissile Materials Disposition (DOE/MD). The scope of the LCC estimate includes:

- design, construction, licensing, operation, and deactivation of a mixed-oxide (MOX) fuel fabrication facility (FFF) that will be used to purify and convert weapons-derived plutonium oxides to MOX fuel pellets and fabricate MOX fuel bundles for use in commercial pressurized-water reactors (PWRs);

- fuel qualification activities and modification of facilities required for manufacture of lead assemblies that will be used to qualify and license this MOX fuel; and

- modification, licensing, and operation of commercial PWRs to allow irradiation of a partial core of MOX fuel in combination with low-enriched uranium fuel.

The baseline cost elements used for this document are the same as those used for examination of the preferred sites described in the site-specific final environmental impact statement and in the DOE Record of Decision that will follow in late 1999. Cost data are separated by facilities, government accounting categories, contract phases, and expenditures anticipated by the various organizations who will participate in the program over a 20 -year period. Total LCCs to DOE/MD are projected at approximately $\$ 1.4$ billion for a 33-MT plutonium disposition mission.
\end{abstract}

\section{INTRODUCTION}

This report is a comprehensive update of several previous documents that provided life cycle cost (LCC) estimates for reactor-based plutonium disposition through the use of mixed-oxide (MOX) fuel. The reactor option was described in the U.S. Department of Energy Office of Fissile Materials Disposition (DOE/MD) programmatic Record of Decision (ROD) ${ }^{1}$ published in January 1997. LCCs for the reactor option do not include costs associated with the Pit Disassembly and Conversion Facility (PDCF) nor those associated with the immobilization of any weapons-grade plutonium. PDCF and immobilization option LCCs are provided in Plutonium Disposition Life Cycle Costs and Cost-Related Comment Resolution Document (November 1999). ${ }^{2}$

This report will provide the background for the first complete public presentation of the reactor-based option LCCs since publication of two supporting documents that accompanied the 1997 ROD. These supporting documents were

- Technical Summary Report for Surplus Weapons-Usable Plutonium Disposition (DOE/ MD-0003, October 1996), ${ }^{3}$ and

- FMDP Reactor Alternative Summary Report: Vol. 1-Existing LWR Alternative (ORNL/ TM-13275/V1, October 1996). ${ }^{4}$ 
An interim report, Cost Analysis in Support of Site Selection for Surplus Weapons-Useable Plutonium Disposition (DOE/MD-0009, July 1998), ${ }^{5}$ presented the design, construction, licensing, and operation costs of two major facilities that would need to be constructed to support the plutonium disposition options. These facilities, the PDCF and the MOX fuel fabrication facility (FFF), were evaluated in this interim report for different candidate sites where the facilities might be located. Since the supporting contractor for the reactor-based option had not yet been chosen in 1998, costs related to fuel qualification, modification, and operation of candidate existing lightwater reactors (LWRs) were not included.

The reactor-based option contractor, Duke/COGEMA/Stone \& Webster (DCS), was selected and placed under DOE contract on March 22, 1999. This report, therefore, presents a more accurate and complete LCC estimate for the reactor option based on a collection, correction, and update of information from:

1. the documents cited above;

2. two design-only conceptual design reports (DO-CDRs): one for the $\mathrm{PDCF}^{6}$ and one for the MOX FFF, ${ }^{7}$ prepared by Fluor-Daniel (F-D) and Los Alamos National Laboratory (LANL);

3. an independent government estimate (IGE) prepared by Oak Ridge National Laboratory (ORNL) prior to negotiation of the mission base contract between DOE and DCS; ${ }^{*}$ and

4. preliminary information obtained from DCS prior to completion of the contract statement of work, cost, and schedule baseline for the project. ${ }^{*}$

A preview of the cost and schedule baseline from the contractor's bid proposal* and the public Environmental Synopsis Report, ${ }^{8}$ April 1999, were also used in preparation of this report.

The estimate presented here does not yet benefit from significant input from DCS or the Savannah River Site (SRS). It is an estimate derived from many sources and is constrained by the requirements of National Environmental Policy Act (NEPA) documentation, information in the DO-CDRs, ${ }^{6,7}$ and other reference information used for preparation of the NEPA documentation. Cost data ${ }^{2}$ for the PDCF and the Immobilization Facility were developed earlier by separate organizations within the DOE/MD. However, there has been a concerted effort to ensure that all cost-estimating categories, procedures, and guidelines were applied on a consistent basis, such that a clear picture of the overall LCCs for all activities within the plutonium disposition program is presented.

The development of this estimate has benefited from several iterations of "reasonableness review" by DOE project staff and by an independent architect/engineer firm. In this manner, the comparability of this estimate with those of other Fissile Materials Disposition Program (FMDP)-proposed plutonium-disposition facilities can be made more likely with regard to base assumptions and methods of presentation. Reviews were also done to assist in the consistent application of contingency or management reserve allowances across all projects.

An updated LCC estimate for the reactor option will be developed in the future. This new estimate will include information from the mission contractor design deliverables such as a Title I MOX FFF design and cost estimate and the project cost and schedule baseline developed from the contract statement of work. Preparation of other contract deliverables within the next 2 years, such as the reactor modification plan and the fuel qualification plan, will also contribute to refinement of the overall contract cost and schedule baseline.

\footnotetext{
* These data sources cannot be released to the public because they contain procurement-sensitive information.
} 


\section{SCOPE OF ESTIMATE}

\subsection{FACILITIES}

The facilities and activities covered in the scope of this estimate are illustrated in Fig. 1. Both the MOX fuel qualification project (production and irradiation of two lead assemblies) and disposition of 33-MT of weapons-grade plutonium (the baseline mission) are included. Existing weapons-grade plutonium dioxide powder and new powder derived from the pit disassembly and conversion demonstration at LANL will be used for fabrication of the lead assemblies in the Technical Area 55 (TA-55) at LANL. These two assemblies will be irradiated at the McGuire Nuclear Station, owned and operated by Duke Power Corporation. Postirradiation examination (PIE) of this lead assembly fuel will take place at ORNL per the preferred PIE site decision of November 12, 1999 (DOE Press release R-99-303).

Most of the 33 MT of plutonium to be dispositioned originates as metallic metal weapons parts or "pits" stored at Defense Programs' (DP's) Pantex facility in Amarillo, Texas. The DOE nuclear material transportation system will use its "safe, secure trailer" (SST) vehicles to transport the weapons parts and any other plutonium materials to the PDCF. The DOE SRS has been chosen as the preferred site for location of the PDCF. At the PDCF, the plutonium metal is converted to $\mathrm{PuO}_{2}$ powder. This powder may have retained some of the residual alloying components that were not totally removed by the pyrochemical processing in the PDCF. The powder is packaged at the PDCF and sent to the closely located MOX FFF. Evaluation of the LCCs for this report begins upon arrival of the $\mathrm{PuO}_{2}$ at the MOX FFF. The FFF initial process is an aqueous polishing step intended to remove the residual impurities to acceptable levels and to produce an acceptable $\mathrm{PuO}_{2}$ powder for use in the $\mathrm{MOX}$ fuel fabrication step. The clean $\mathrm{PuO}_{2}$ is blended with clean depleted $\mathrm{UO}_{2}$ powder to form a mixture that averages about $4.3 \% \mathrm{PuO}_{2}$. The mixture is formed into pellets, sintered, and loaded into rods that are then bundled into MOX fuel assemblies. These assemblies appear very similar to the low-enriched uranium (LEU) assemblies. After fabrication, the MOX assemblies are packaged in a special three-bundle shipping package and transported by SST to the six pressurized-water reactors (PWRs) that DCS has designated to provide irradiation services. The reactors to be used are three two-unit plants at the McGuire Nuclear Station (Duke Power Co.) just north of Charlotte, North Carolina; the Catawba Nuclear Station (Duke Power Co.) located near Lake Wylie, South Carolina; and the North Anna Nuclear Power Station (Virginia Power Co.) northwest of Richmond, Virginia. All MOX assemblies will be irradiated to a level equivalent or greater than the "spent fuel standard" concept advanced by the National Academy of Sciences (NAS). Once the spent MOX fuel is discharged from the reactors, it will be handled in the same way as spent LEU fuel. Spent fuel disposal is covered by a 1-mill/kWh fee paid by the utilities to the DOE Office of Civilian Radioactive Waste Management $(\mathrm{RW})$. No additional costs are anticipated for disposal of MOX spent fuel compared to disposal of LEU spent fuel.

\subsection{TEMPORAL SCOPE}

LCCs presented here are projected costs for FY 2000 and beyond. Programmatic alreadyspent or "sunk" costs, which are also included in the final ROD documentation, ${ }^{2}$ are listed separately as a single estimating category. Sunk costs were determined from DOE/MD budget records. Sunk costs for DCS activities are accumulated from the time of the signing of the DCS contract in March 1999. The major LCC categories considered in this report are remaining research and development $(\mathrm{R} \& \mathrm{D})$, the fuel qualification project, development of management plan deliverables, and new facility design, modification design, startup, operation, deactivation, and ultimate decommissioning. Also included are effective credits to DOE for part of the value of the LEU fuel assemblies displaced by MOX fuel assemblies. 


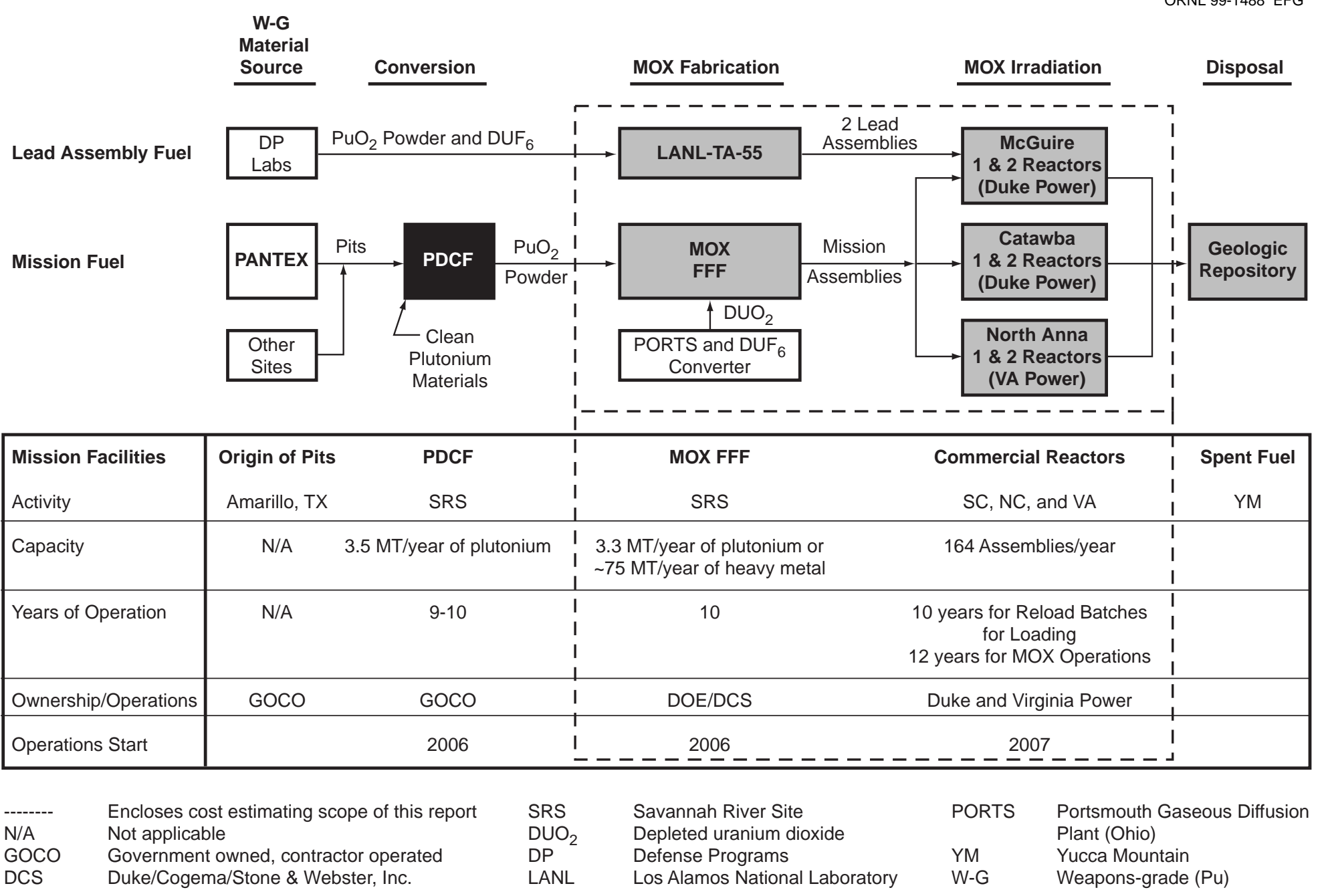

Note: In addition to MOX mission assemblies shown above, LEU assemblies will be utilized to make up a reload batch of fuel.

Fig. 1. Reference facilities for reactor-based portion of dual-track plutonium disposition option. 


\section{LCC SUMMARY}

Tables 1(a) and 1(b) show the major LCC elements for all facilities in lump sum FY 2000 constant million dollars and also provide word descriptions of the cost elements. Fuel qualification and new fuel transportation have been listed as separate activities. Projected costs for the MOX FFF Congressional line item project have been estimated separately from other up-front costs such as those associated with the modification, licensing and operation of the mission reactors. The up-front total cost for line items is referred to as total project cost (TPC). The TPC consists of two parts depending on the type of Congressional appropriation. Operations-funded project cost (OPC), funded out of the operating budget, and total estimated cost (TEC), funded out of the capital budget, are accumulated separately.

The remaining up-front costs (non-OPC) are funded out of the DOE operating budget for items that are not within the scope of a particular Congressionally authorized facility. Examples are DCS fuel qualification activities and modifications to privately owned reactors. The other major LCC elements are recurring costs, which for purposes of this estimate are assumed to remain the same in constant dollars for 10-12 years of the mission facilities lifetimes, and end-oflife (EOL) costs, which include final deactivation and decontamination and decommissioning (D\&D) costs.

\subsection{FUEL QUALIFICATION}

The goal of the fuel qualification program is to successfully design, fabricate, irradiate, and examine two prototypic MOX PWR lead assemblies. The fuel qualification project is used to confirm to the regulatory authority that it is safe to use MOX fuel in U.S. reactors. The fuel qualification effort is a joint effort between DCS, the lead assembly fabrication site, and the national laboratory that will conduct supporting PIEs. The total cost of $\sim \$ 120 \mathrm{M}$ for qualification of MOX fuel includes DCS management and fees, the lead assembly facility (preferred site is Building TA-55 at LANL) upgrades and operations, special process equipment to be provided by DCS, PIE at a national laboratory (preferred site is ORNL), preparation of documents to support the license amendment for insertion of the two lead assemblies in McGuire Unit-2, a programmatic contingency of $38.5 \%$ recommended for TA-55 activities, and a 10\% management reserve for DCS fuel qualification activities. Duke Power Company irradiation fees at the McGuire Nuclear Station are also included. Approximately $\$ 56 \mathrm{M}$ (with contingency) of these funds are for TA-55 personnel services and TA-55 upgrades. Approximately $\$ 22 \mathrm{M}$ is for TA-55 facility "rent" from DOE/DP (infrastructure). The remaining \$24M in fuel qualification costs are for DCS supervision and DCS-supplied special equipment plus PIE and NRC license amendment reviews.

\subsection{MOX FFF}

The documented design basis for the FFF project is currently the DO-CDR, ${ }^{7}$ which was prepared in late 1997 and updated in 1998 to consider use of the SRS site. [The MOX FFF project baseline in the DO-CDR (technical cost and schedule) will eventually be replaced by the European MELOX-based plant design proposed by DCS. This new baseline plant concept will have an adjusted cost and schedule based on the evolving DCS design.] The DO-CDR MOX FFF design was based on a generic MOX plant design that was prepared for use in NEPA documentation, site evaluation, and submission of an out-year design budget for the reactor-based disposition program. The DO-CDR MOX FFF is capable of producing up to 195 Westinghouse-type PWR MOX fuel assemblies (similar to fuel to be used by DCS) annually and, for NEPA purposes, was assigned a mission time of 10 years. To accommodate six DCS PWRs, a fuel cycle requiring 164 assemblies per year was analyzed. For this estimate, a TPC (design, construction, and cold startup cost) of $\$ 723 \mathrm{M}$ has been calculated from the SRS-sited DO-CDR estimate and includes the addition of design/construction cost data for the aqueous polishing portion of the MOX FFF building not included in the DO-CDR but covered separately in the final EIS. ${ }^{9}$ Note that all DOCDR derived costs have been escalated from 1997 constant dollars to 2000 constant dollars. 
Table 1(a). Reactor-based disposition option LCC summary (FY 2000 constant \$M)

\begin{tabular}{|c|c|c|c|c|c|c|c|c|c|c|}
\hline \multirow[b]{3}{*}{ Row No. } & \multirow[b]{3}{*}{ Facility/activity } & (A) & (B) & $C=(A+B)$ & (D) & $\mathrm{E}=(\mathrm{C}+\mathrm{D})$ & (F) & $(\mathrm{G})$ & $(\mathrm{H})$ & $\mathrm{I}=(\mathrm{E}+\mathrm{F}+\mathrm{G}+\mathrm{H})$ \\
\hline & & \multicolumn{5}{|c|}{ Up-front (investment) costs ${ }^{a}$} & \multicolumn{2}{|c|}{ Mission recurring costs } & \multirow{2}{*}{$\begin{array}{c}\text { EOL costs } b \\
\text { Deactivation/ } \\
\text { D\&D } \\
\text { costs }\end{array}$} & \multirow[b]{2}{*}{$\begin{array}{l}\text { Total } \\
\text { LCC }\end{array}$} \\
\hline & & $\begin{array}{l}\text { OPC } \\
\text { costs }\end{array}$ & $\begin{array}{l}\text { Line item } \\
\text { (TEC) } \\
\text { costs }\end{array}$ & $\begin{array}{l}\mathrm{TPC} \\
\text { costs }\end{array}$ & $\begin{array}{l}\text { Other } \\
\text { up-front } \\
\text { costs }\end{array}$ & $\begin{array}{l}\text { Total } \\
\text { up-front } \\
\text { costs }\end{array}$ & $\begin{array}{l}\text { Operations } \\
\text { costs }\end{array}$ & $\begin{array}{c}\text { Fuel } \\
\text { displacement } \\
\text { credit }\end{array}$ & & \\
\hline & $\begin{array}{l}\text { Reactor-based (33 MT } \\
\text { of plutonium) }\end{array}$ & & & & & & & & & \\
\hline 1 & Fuel qualification $^{c}$ & & & & 120 & 120 & & & & 120 \\
\hline 2 & MOX FFF & 157 & 566 & 723 & & 723 & 763 & -568 & 59 & 977 \\
\hline 3 & $\begin{array}{l}\text { Existing reactors } \\
\text { (6 PWRs) }\end{array}$ & & & & 136 & 136 & 150 & & & 286 \\
\hline 4 & Transportation & & & & 7 & 7 & 10 & & & 17 \\
\hline & Total & 157 & 566 & 723 & 263 & 986 & 923 & -568 & 59 & 1400 \\
\hline
\end{tabular}

$a_{\mathrm{OPC}}=$ Operations-funded up-front costs for MOX FFF design/construction project (\$102M in sunk costs are also included in this category)

TEC $=$ Total estimated cost (capital or Congressional line item funded cost for MOX FFF)

TPC $=$ Total project cost for MOX FFF

Other "up-front" costs represent government investments for reactor modification and transportation equipment.

$b_{\mathrm{EOL}}=$ End-of-life costs.

${ }^{c}$ Includes DCS management of fuel qualification activities plus management reserve. See Appendix A for content of categories.

Note: Column and row numbers are provided for traceability to Table 5 detailed categories and Table 1(b). 
Table 1(b). Cost elements within Table 1(a) LCCs

\begin{tabular}{|c|c|c|}
\hline $\begin{array}{l}\text { Column and } \\
\text { row }\end{array}$ & Name & $\begin{array}{l}\text { Cost elements } \\
\text { (cost numbers can be found in Table 5) }\end{array}$ \\
\hline D1 & Fuel qualification & $\begin{array}{l}\text { Lead assembly program (LANL, DCS, and PIE costs), } \\
\text { prorated DCS fee, lead assembly license amendment } \\
\text { preparations and support, DOE management reserve }\end{array}$ \\
\hline $\mathrm{A} 2$ & MOX FFF OPC & Sunk costs, NRC activities, host site design support \\
\hline B2 & MOX FFF TEC & $\begin{array}{l}\text { Design, license application, equipment procurement, } \\
\text { construction, permits, construction management and } \\
\text { fees, host site support, design reviews, inspections } \\
\text { (Title III), DOE management reserve, cold startup }\end{array}$ \\
\hline $\mathrm{F} 2$ & MOX FFF operations & $\begin{array}{l}\text { NRC inspections and regulation, labor, fuel assembly } \\
\text { and other consumables, utilities, } \text { DUF }_{6} \text { to } \mathrm{DUO}_{2} \text { con- } \\
\text { version, waste disposal, hot startup, fee to DCS }\end{array}$ \\
\hline G2 & $\begin{array}{l}\text { LEU displacement } \\
\text { credit }\end{array}$ & $\begin{array}{l}\text { Discounted value of displaced LEU fuel cycle materials } \\
\text { and services }\end{array}$ \\
\hline $\mathrm{H} 2$ & $\begin{array}{l}\text { MOX FFF deactiva- } \\
\text { tion and D\&D }\end{array}$ & $\begin{array}{l}\text { DCS deactivation costs, host site D\&D costs for MOX } \\
\text { FFF }\end{array}$ \\
\hline D3 & Reactor up-front costs & $\begin{array}{l}\text { National laboratory reactor-related R\&D, DCS home } \\
\text { office management (base contract), reactor modifica- } \\
\text { tion design and construction, core design and reload } \\
\text { analysis, permits, reload license amendment, and DOE } \\
\text { management reserve }\end{array}$ \\
\hline F3 & Reactor operations & $\begin{array}{l}\text { Fee to contractor during option 2, incremental costs to } \\
\text { utilities (additional people, casks, boron, control rods, } \\
\text { etc.), additional enrichment cost for MOX adjacent } \\
\text { LEU assemblies }\end{array}$ \\
\hline D4 & $\begin{array}{l}\text { Transportation up- } \\
\text { front costs }\end{array}$ & $\begin{array}{l}\text { MO-1 lead assembly package recertification, mission } \\
\text { shipping package design, certification, fabrication, and } \\
\text { procurement }\end{array}$ \\
\hline $\mathrm{F} 4$ & $\begin{array}{l}\text { Transportation } \\
\text { operations }\end{array}$ & $\begin{array}{l}\text { SST shipment of MOX bundles from MOX FFF to } \\
\text { reactor sites }\end{array}$ \\
\hline
\end{tabular}

Recurring costs in the SRS-adjusted DO-CDR were estimated at \$57M/year in 1997 dollars for 10 years and did not include an aqueous polishing step at the front end of the facility. This cost has been adjusted for escalation, a different imbedded fee structure, the addition of more than $\$ 11 \mathrm{M} /$ year for aqueous polishing, increased waste treatment, and altered use of consumables. Table 2 shows how the transition from the DO-CDR operations costs to the current costs have been accomplished. If the government operated this plant in the typical management and operating $(\mathrm{M} \& \mathrm{O})$ contractor manner, where all $\mathrm{M} \& \mathrm{O}$ costs are reimbursed to the contractor, a cost of more than $\$ 62 \mathrm{M} /$ year would result, not including fees to the $\mathrm{M} \& \mathrm{O}$ contractor. As will be seen below, option 2 of the DOE mission contract provides for a different funding concept for MOX FFF operations, that is, one in which the contractor bears most of the cost risk.

\subsection{FUEL DISPLACEMENT CREDIT}

The use of partial MOX reloads is projected to save $\$ 86 \mathrm{M} /$ year (for 10 years for a total of $\$ 860 \mathrm{M}$ ) in LEU fuel purchase costs for the LEU assemblies which were displaced by MOX assemblies. This savings assumes that LEU fuel costs are $\$ 1127 / \mathrm{kgU}$ based on the following LEU component costs: $\$ 12 / 1 b \mathrm{U}_{3} \mathrm{O}_{8}$ (ore), $\$ 5 / \mathrm{kgU}$ (natural $\mathrm{U}_{3} \mathrm{O}_{8}$ to $\mathrm{UF}_{6}$ conversion), $\$ 90 / \mathrm{SWU}$ (enrichment service), and $\$ 180 / \mathrm{kgU}$ (PWR assembly fabrication). An enrichment tails assay of $0.3 \%{ }^{235} \mathrm{U}$ is assumed along with a $10 \%$ carrying charge on the LEU assembly total cost. Table 3 
Table 2. Adjustment of MOX FFF recurring costs from DO-CDR values to reflect revised mission

\begin{tabular}{|c|c|c|}
\hline Expense & Annual cost & Comment \\
\hline \multicolumn{3}{|c|}{ Breakdown of DO-CDR MOX recurring (operations) costs (SRS revision) } \\
\hline 10 years of operations // 195 PWR assemblies/year & (1997 \$M/year) & \\
\hline Direct and indirect labor not including $10 \%$ fee & 29.47 & Based on staff of 350 without aqueous polish @ $\$ 84,200 /$ year average \\
\hline $\mathrm{UF}_{6}$ to $\mathrm{UO}_{2}$ conversion and transport to $\mathrm{MOX} F F F$ & 0.50 & $\mathrm{DUF}_{6}$ to $\mathrm{DUO}_{2}$ conversion service in $\$ 6-7 / \mathrm{kgU}$ range \\
\hline Zirconium and stainless steel assembly hardware & 11.20 & Based on 195 PWR assemblies/year \\
\hline Other consumables ${ }^{a}$ & 8.00 & Based on 195 PWR assemblies/year \\
\hline Regulation and inspection $b$ & 3.00 & $\$ 3 \mathrm{M} /$ year in 1997 dollars per DO-CDR paid to NRC \\
\hline Utilities (gas, water, electricity) $b, c$ & 0.50 & Funded by DOE through site \\
\hline Waste disposal $a, b, c$ & 1.30 & Assumes no aqueous polishing \\
\hline Imbedded fee ( $10 \%$ added to staffing by F-D) & 2.95 & To be replaced with consortium fee \\
\hline Annual total per DO-CDR adjusted for SRS & 56.92 & \\
\hline
\end{tabular}

Adjustment of DO-CDR MOX recurring (operations) costs ${ }^{c}$

10 years of operations // 164 PWR assemblies: adjusted

for aqueous polish, number of assemblies, fee

Direct and indirect labor not including $10 \%$ fee markup (SRS)

Additional operations for aqueous polishing (SRS)

$\mathrm{UF}_{6}$ to $\mathrm{UO}_{2}$ conversion and transport to MOX FFF

Zirconium and stainless steel assembly hardware

Other consumables ${ }^{a}$

\section{(1999 \$M/year)}

30.20 Based on staff of 350 without aqueous polish @ \$86,285/year

(1999\$)

8.10 Adds 85 additional staff plus other in-plant costs

0.50 Conversion service in $\$ 6-7 / \mathrm{kgU}$ range

9.42 Based on 164 PWR assemblies/year

Regulation and inspection ${ }^{b}$

6.73 Based on 164 PWR assemblies/year

Utilities (gas, water, electricity) $)^{b, c}$

3.11 To be paid to NRC

Waste disposal $b, c$

0.52 To be in budget of SRS as GFS

Imbedded fee ( $10 \%$ added to staffing by FD in

3.17

DO-CDR)

Adds handling of additional wastes ${ }^{d}$

0.00 To be replaced with consortium fee later

Total per adjustments

61.75

$-6.80$

Annual government supplied services (utilities, regulation, infrastructure, waste disposal)

54.95

Annual costs to DCS

${ }^{a}$ Chemicals, maintenance materials. etc.

$b_{\text {Indicates government supplied service. }}$

${ }^{c}$ Also to be in SRS budget as GFS.

$d_{\text {Table } 5 \text { escalates these to year } 2000 \text { constant dollars. }}$ 
Table 3. Material and service components of LEU fuel displaced by MOX fuel

\begin{tabular}{lccc}
\hline \multicolumn{1}{c}{ Commercial cost basis } & $\begin{array}{c}\text { Unit fuel } \\
\text { assembly basis } \\
(\$ \mathrm{M})\end{array}$ & $\begin{array}{c}\text { Component } \\
(\%)\end{array}$ & $\begin{array}{c}\text { Cost } \\
(\$ / \mathrm{kg} \mathrm{LEU})\end{array}$ \\
\hline Uranium ore component & 0.136 & 26.06 & 294 \\
Conversion $\left(\mathrm{U}_{3} \mathrm{O}_{8}\right.$ to $\left.\mathrm{UF}_{6}\right)$ component & 0.022 & 4.18 & 47 \\
SWU component (enrichment) & 0.234 & 44.70 & 504 \\
Bundle fabrication $\mathrm{UF}_{6}$ to $\mathrm{UO}_{2}$ & 0.084 & 15.97 & 180 \\
Carrying charge & $\underline{0.048}$ & $\underline{9.09}$ & $\frac{102}{1127^{a}}$ \\
$\quad$ Total & 0.523 & 100.00 & 100 \\
\hline
\end{tabular}

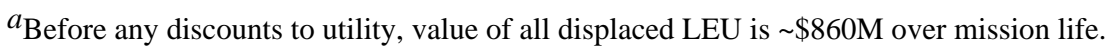

shows how the LEU costs break down on a per assembly and per kilogram of enriched uranium (EU) basis. The average enrichment of the LEU assemblies for an all-LEU core is assumed to be $4.17 \%{ }^{235} \mathrm{U}$ which is typical of the fuel used in Duke Power Company PWRs. Because of the significant fuel savings, DOE has specified in its contract with DCS that DCS pay the majority of the MOX plant operational (recurring) cost. DCS has in turn requested a significant discount on the projected cost of the LEU displaced, that is, a reduced effective credit to the government. This discount is perceived to compensate the DCS participating utilities for the financial risk being taken to their multibillion dollar nuclear plant assets. The actual displacement credit will depend on the following factors: (1) the LEU constituent material and service prices at the time that the core reload order is made with the LEU fabricator, (2) the actual cost of operating the MOX FFF during the preceding operating cycle, (3) the fee required by the MOX FFF licensed operator, (4) cost/benefit sharing clauses in the DCS contract, and (5) the cost of government-furnished services (GFS) such as utilities and infrastructure cost from the FFF host site that have been provided by DOE. In simplistic terms, the government pays, or is paid, the difference between the discount-adjusted value of the LEU fuel displaced and the experienced cost of producing the MOX assemblies required for the reload. This will be a continuing issue because, on average, 2.5 reload batches of MOX fuel will be needed each year of operation. For the hypothetical case presented here, a credit of $\$ 568 \mathrm{M}$ is assumed. This credit reduces DOE's program cost for operation of the FFF from $\$ 763 \mathrm{M}$ to $\$ 195 \mathrm{M}$ for 10 years of MOX FFF operations including the cost of the original hot startup of the MOX FFF. This hypothetical credit represents a significant discount to the utilities on the market value $(\$ 860 \mathrm{M})$ of displaced LEU fuel.

The actual multiplication factor (ratio of discounted LEU fuel value to the market LEU value) was negotiated between DOE and DCS. The factor is business sensitive and cannot be publicly released but is between 0.5 and 0.9 . A value of approximately 0.7 was used in this estimate.

\subsection{MOX FFF END-OF-LIFE COSTS}

DCS will be responsible for deactivation of the MOX FFF after 10 years of operation. This task, which involves removal of process plutonium from the glove boxes and sealing of the boxes, has been assigned a ceiling cost to DOE of $\$ 10 \mathrm{M}$. The actual price will be determined when option 3 of the DOE contract is negotiated. ${ }^{*}$ An additional $\$ 49 \mathrm{M}$ will be needed by the host site for costs associated with removal of the equipment and glove boxes from the building, radwaste disposal,

\footnotetext{
*The DCS "base contract" covers design of the MOX FFF, design of reactor modifications, fuel qualification, and preparation and submittal of the MOX FFF license application. Contract option 1 covers MOX FFF construction and cold startup plus modification of reactors. Contract option 2 includes hot startup of the MOX FFF, "at-risk" (financial) operation of the MOX FFF, and incremental cost of operation of the six reactors on MOX fuel. Contract option 3 covers deactivation of the MOX FFF.
} 
and return of the building to a habitable condition for possible use by other DOE missions. This amount also includes funding for the NRC to approve the deactivation plans.

\subsection{IRRADIATION SERVICES}

The $\sim \$ 136 \mathrm{M}$ in nonfuel qualification reactor-related up-front costs are for core design, reactor system modification design, and actual modification and licensing of the six PWRs for use of partial MOX cores. The modification cost estimate is based on the 1996 Reactor Alternative Summary Report (RASR) studies. ${ }^{4}$ In the future, DCS will produce a reactor modification plan and design concept that will provide a more accurate estimate of system modification costs. A new cost, schedule, and technical baseline for irradiation services will be developed within the next 2 years.

The $\$ 150 \mathrm{M}$ in projected operational costs and fees (to utilities and DCS home office) is spread over 12 years for reactor incremental operational costs, such as extra personnel, more boron chemical additions, and possible new types or additional control rods. Fuel loading costs are spread over 10 years to align with the period of MOX FFF operations and to avoid the storage of hundreds of MOX fuel assemblies; however, reactor operations, which are based upon utility commitments, etc., will probably dictate some variations from the base plan. There is also a small incremental charge related to the need to increase the amount of ${ }^{235} \mathrm{U}$ enrichment in LEU assemblies which are located adjacent to fresh MOX assemblies $\left(4.3 \%{ }^{235} \mathrm{U}\right.$ vs $4.17 \%$ in an all-LEU core). This need is brought about to reduce neutron flux peaking at certain regions of the mixed core. This reactor physics-related difference results in additional uranium and enrichment charges to the utility from the LEU fabricator during the MOX mission.

The use of MOX in PWRs is not projected to impose any additional large facility deactivation, reactor $\mathrm{D} \& \mathrm{D}$, or spent fuel disposal charges on the participating utilities. A $\$ 9 \mathrm{M} /$ year incremental operations charge (part of the $\$ 150 \mathrm{M}$ total above) is included to cover any additional boron chemicals, transportation or storage casks, control rods, etc., required by MOX use. Table 4 shows the fuel cycle parameters for the disposition mission assumed in this report.

\subsection{TRANSPORTATION}

A total mission cost of approximately $\$ 10 \mathrm{M}$ is projected for SST transport of the fresh MOX fuel assemblies from the MOX FFF to the three reactor sites. SRS was assumed as the point of origin. A special three-bundle transportation package to be designed and fabricated by DCS will be used. The up-front cost of acquiring the eight mission transportation packages is estimated at approximately $\$ 2 \mathrm{M}$. The remaining $\$ 5 \mathrm{M}$ in up-front costs is assumed to cover contractor, national laboratory, and NRC shipping package certification activities.

\subsection{LCC TABLES}

Table 5 presents the LCCs in the same format used to prepare the DOE/MD LCC document ${ }^{2}$ supporting the ROD and is designed to show how data from the MOX FFF DO-CDR were utilized. In that study, ${ }^{2}$ similar cost categories are utilized to present PDCF and immobilization LCCs along with those for the reactor-based option. Total reactor-based LCCs are approximately $\$ 1.4$ billion in constant FY 2000 dollars. These costs do not include the LCCs of the PDCF.

Table 6 compares the LCCs reported here to those projected in the 1996 ORNL RASR studies. ${ }^{4}$ The reasons for the cost increases or decreases are shown on the table.

In summary, this new estimate is more accurate than the 1996 estimate because most data are now derived from conceptual design reports (the DO-CDR) and from projections made by the contractor, DCS, who will actually implement the program. It is also apparent that the risksharing consortium concept being implemented should result in significant savings to DOE and taxpayers over a hypothetical similar mission performed in the usual DOE GOCO contractor mode. 
Table 4. Fuel cycle data on which LCCs (MOX FFF and irradiation services) are based

\begin{tabular}{|c|c|c|}
\hline Attribute & Value & Comments \\
\hline Total plutonium available for reactor-based disposition, ${ }^{a} \mathrm{MT}$ & 33 & Basic assumption in DO-CDR \\
\hline Duration of operations for MOX FFF and initial loading of PWRs, ${ }^{a}$ years & 10 & Basic assumption in DO-CDR \\
\hline PWRs available $a$ & 6 & Publicly announced by $\mathrm{DCS}^{b}$ on March 22, 1999 \\
\hline HM mass of a fuel assembly, MT/assembly ${ }^{a}$ & 0.464 & Typical mass of Westinghouse PWR assembly (HM) \\
\hline PWR MOX assemblies/year per DO-CDR ${ }^{a}$ & 164 & $\begin{array}{l}\text { DO-CDR gives } 195 \text { as maximum for PWR, DCS } \\
\text { suggests } 164\end{array}$ \\
\hline Average throughput of MOX FFF, MT/year of HM & 76.1 & Calculated from two entries above \\
\hline Annual plutonium throughput, MT/year & 3.3 & Calculated for 10-year campaign \\
\hline Average plutonium concentration in HM (mass fraction) for MOX assemblies & 0.0434 & Calculated from two entries above \\
\hline Average power capacity of PWR, ${ }^{a} \mathrm{MW}(\mathrm{e})$ & 3411 & $\begin{array}{l}\text { Typical of Westinghouse reactor such as McGuire or } \\
\text { Catawba }\end{array}$ \\
\hline Fuel assemblies in PWR core (Westinghouse PWR) ${ }^{a}$ & 193 & $\begin{array}{l}\text { Typical of Westinghouse reactor such as McGuire or } \\
\text { Catawba }\end{array}$ \\
\hline Average time between refuelings, years & 1.5 & $\begin{array}{l}\text { Typical of Westinghouse reactor such as McGuire or } \\
\text { Catawba }\end{array}$ \\
\hline Reloads per reactor over mission & 6.67 & Calculated \\
\hline Total reloads for all reactors in mission & 40 & Calculated \\
\hline Total assemblies $(\mathrm{MOX}+\mathrm{LEU})$ in a partial MOX PWR reload ${ }^{a}$ & 84 & $\begin{array}{l}\text { Typical of Westinghouse reactor such as McGuire or } \\
\text { Catawba }\end{array}$ \\
\hline Co-resident LEU assemblies in a partial MOX reload ${ }^{a}$ & 43 & \\
\hline LEU assemblies in an all-LEU reload ${ }^{a}$ & 84 & \\
\hline MOX assemblies available per reload (averaged) ${ }^{c}$ & 41 & Calculated \\
\hline Fraction of entire core that is MOX at equilibrium & 0.49 & $\begin{array}{l}\text { Calculated (if mission load time were increased, this } \\
\text { fraction would be lower) }\end{array}$ \\
\hline Fraction of entire core that is reloaded at each refueling for MOX & 0.44 & Assumes MOX fuel twice burned \\
\hline Fraction of all-LEU core that is reloaded at each refueling & 0.44 & Most fuel twice burned, some thrice burned \\
\hline Average ${ }^{235} \mathrm{U}$ enrichment of all-LEU core (needed for LEU credit calculation) ${ }^{a}$ & 0.0417 & $\begin{array}{l}\text { Typical of Westinghouse reactor such as McGuire or } \\
\text { Catawba }\end{array}$ \\
\hline $\begin{array}{l}\text { Average }{ }^{235} \mathrm{U} \text { enrichment of co-resident LEU [surrounds MOX, needed for uranium } \\
\text { enrichment (UE)-penalty calculation }]^{a}\end{array}$ & 0.043 & $\begin{array}{l}\text { Typical of Westinghouse reactor such as McGuire or } \\
\text { Catawba }\end{array}$ \\
\hline LEU assemblies used in campaign if no MOX (for calculation of LEU reload value) & 3360 & Based on DCS data \\
\hline Co-resident LEU assemblies used in MOX campaign (for calculation of UE-penalty) & 1720 & \\
\hline $\begin{array}{l}\text { LEU assemblies displaced by MOX during campaign (for calculation of displaced } \\
\text { credit) }\end{array}$ & 1640 & \\
\hline
\end{tabular}

\footnotetext{
$a_{\text {Indicates that value is an input to model. }}$

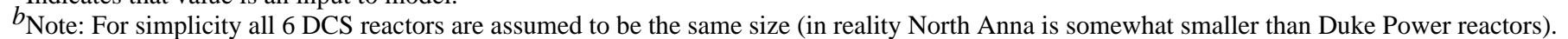

${ }^{c}$ The actual fuel cycles will be designed by utilities to match their fuel requirements for their particular reloads. The actual reload configurations will be more complicated than represented in this illustrative example. The above idealized fuel cycle was designed to correspond to the NEPA MOX FFF 10-year operational requirement.
} 
Table 5. Reactor program cost estimate summaries by major categories FY 2000 undiscounted dollars, including transitions from original MOX FFF DO-CDR

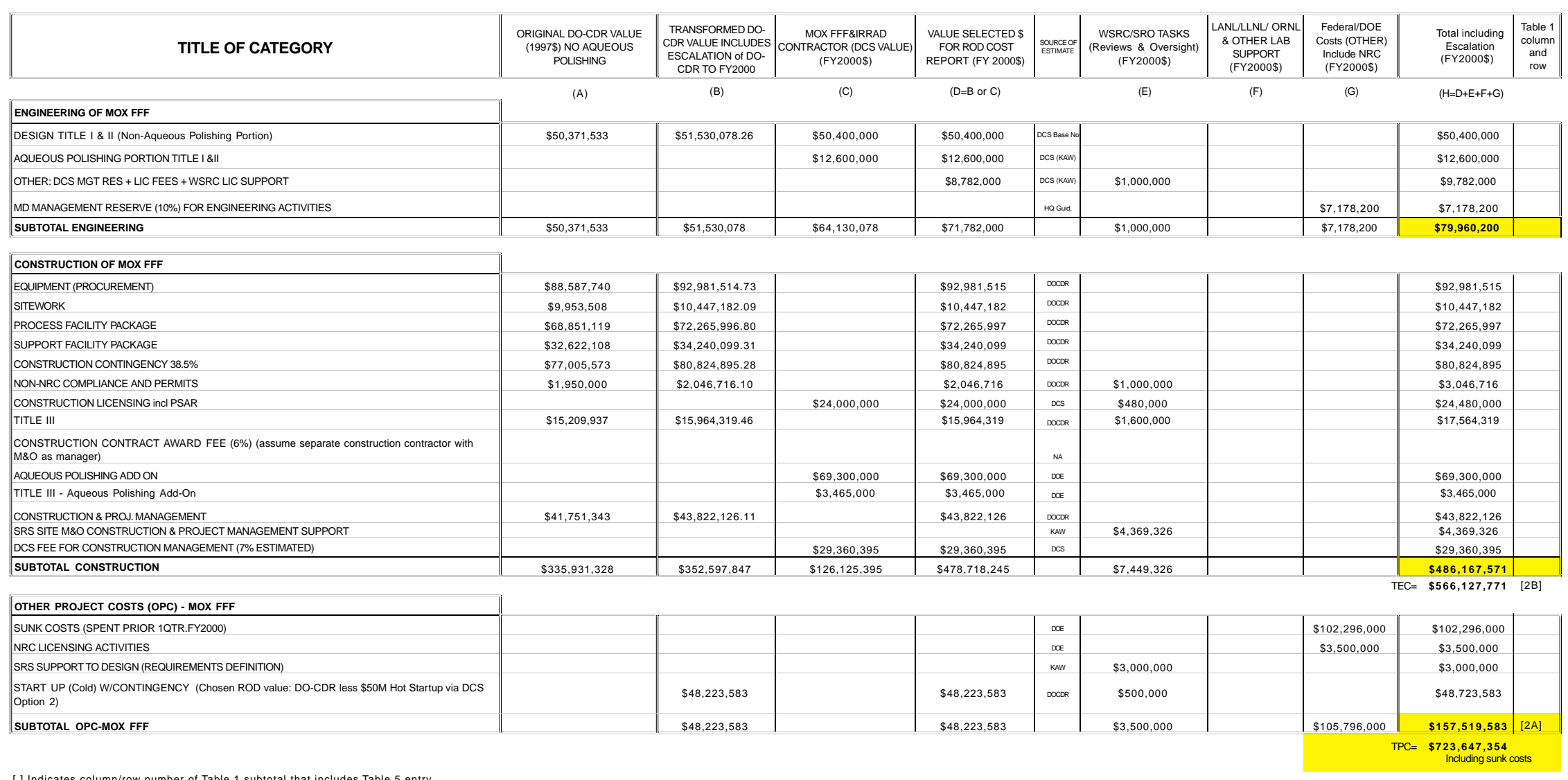


Table 5. (continued)

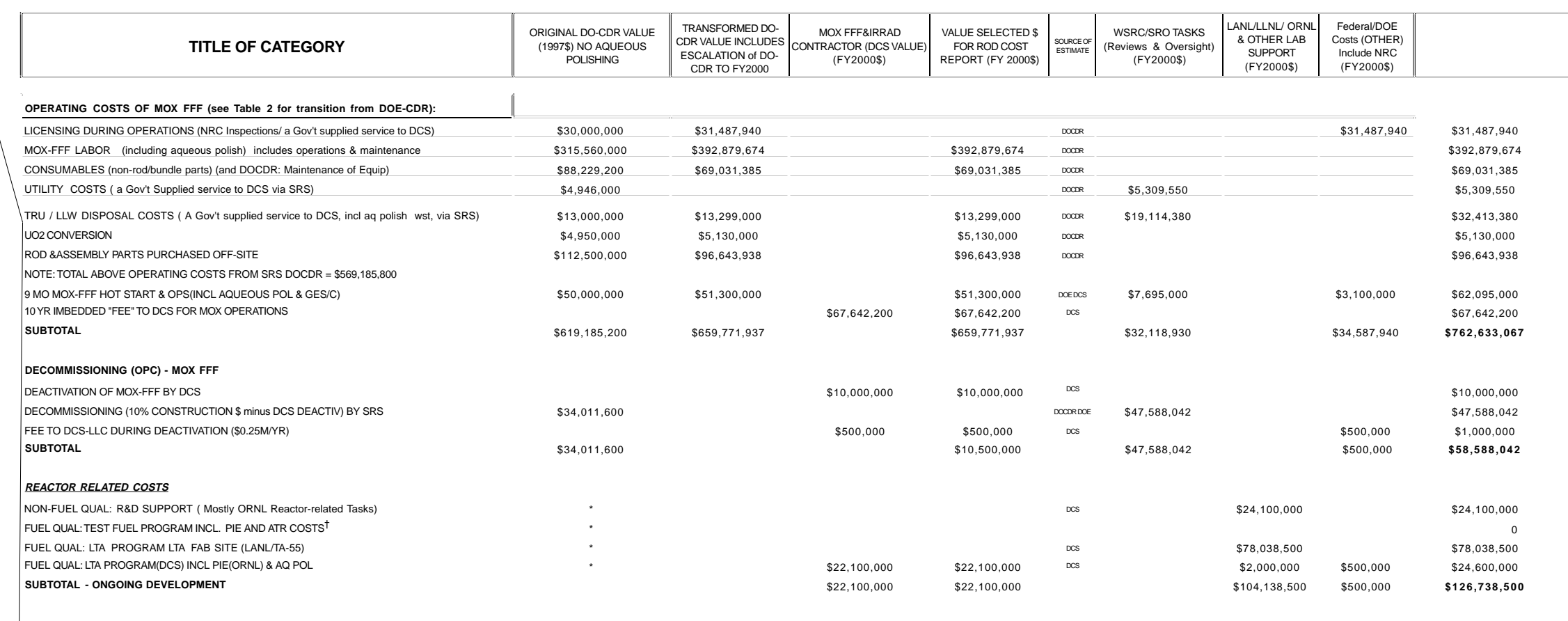


Table 5. (continued)

\begin{tabular}{|c|c|c|c|c|c|c|c|c|c|c|}
\hline TITLE OF CATEGORY & $\begin{array}{l}\text { ORIGINAL DO-CDR VALUE } \\
\text { (1997\$) NO AQUEOUS } \\
\text { POLLSHING }\end{array}$ & 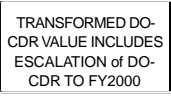 & $\begin{array}{c}\text { MOX FFF\&IRRAD } \\
\text { CONTRACTOR (DCS VALUE) } \\
\text { (FY2000\$) }\end{array}$ & $\begin{array}{l}\text { VALUE SELECTED \$ } \\
\text { FoR ROD COST } \\
\text { REPORT (FY 2000\$) }\end{array}$ & 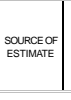 & $\begin{array}{c}\text { WSRC/SRO TASKS } \\
\text { (Reviews \& Oversight) } \\
\text { (FY2000\$) }\end{array}$ & $\mid \begin{array}{l}\text { LANLLLNLL ORNL } \\
\text { \& OTHER LAB } \\
\text { SUPPORT } \\
\text { (FY2000\$) }\end{array}$ & $\begin{array}{l}\text { Federal/DOE } \\
\text { Costs (OTHER) } \\
\text { Include NRC } \\
\text { (FY2000\$) }\end{array}$ & $\begin{array}{l}\text { Total including } \\
\text { Escalation } \\
\text { (FY2000\$) }\end{array}$ & \begin{tabular}{|c|}
$\mid \begin{array}{c}\text { Table } 1 \\
\text { column } \\
\text { and } \\
\text { row }\end{array}$ \\
\end{tabular} \\
\hline \multicolumn{11}{|l|}{ REACTOR RELATED COSTS (continued) } \\
\hline 5YRDCS HOME OFFICE MANAGEMENT & . & & $\$ 13,300,000$ & $\$ 13,300,000$ & ocs & $\$ 200,000$ & & & $\$ 13,500,000$ & [D3] \\
\hline REACTOR MODIFICATION DESIGN \& PLANNING & . & & $\$ 10,500,000$ & $\$ 10,500,000$ & ocs & & $\$ 200,000$ & & $\$ 10,700,000$ & [D3] \\
\hline REACTOR CORE DESIGN, MGT PLAN, \& OPERATION PLAN & . & & $\$ 3,400,000$ & $\$ 3,400,000$ & oss & & $\$ 400,000$ & & $\$ 3,800,000$ & [D3] \\
\hline REACTOR LIC. PLAN, LIC. AMENDMENT APPL, RL REPORT \& PERMT'G & . & & $\$ 2,700,000$ & $\$ 2,700,000$ & ocs & & $\$ 200,000$ & $\$ 1,100,000$ & $\$ 4,000,000$ & [D3] \\
\hline DESIGNDEVELOPMENT/FAB/PROC OF LTA SHIPPING CASK (MO-1) & * & & $\$ 500,000$ & $\$ 500,000$ & os & & $\$ 500,000$ & $\$ 100,000$ & $\$ 1,100,000$ & [D4] \\
\hline MISSION MOX TRANSPORTATION PLANNING \& CASK CERTIFICATION & . & & $\$ 100,000$ & $\$ 100,000$ & ocs & & $\$ 4,000,000$ & $\$ 500,000$ & $\$ 4,600,000$ & [D4] \\
\hline FEE TO CONTRACTOR FOR BASE CONTRACT (nonFFF related) & . & & $\$ 4,189,000$ & $\$ 4,189,000$ & ocs & & & & $\$ 4,189,000$ & [D1] \\
\hline REACTOR MODIFICATION INCLUDING EQUIPMENT \& SITE MODS & . & & $\$ 75,001,207$ & $\$ 75,001,207$ & ocs & & & & $\$ 75,001,207$ & [D3] \\
\hline PROCUREMENT OF MISSIONFRESH SHPING CASKS & . & & $\$ 1,500,000$ & $\$ 1,500,000$ & oss & & & & $\$ 1,500,000$ & [D4] \\
\hline REACTOR LICENSE AMENDMENT ACTIVITIES NOT IN BASE CONTRACT & . & & $\$ 2,700,000$ & $\$ 2,700,000$ & ocs & & $\$ 1,000,000$ & $\$ 4,400,000$ & $\$ 8,100,000$ & [D1] \\
\hline MD MANAGEMENT RESERVE FOR DCS BASE CONTRACT ACTIVITIES & . & & & & $\infty$ & & & $\$ 4,800,000$ & $\$ 4,800,000$ & [D1] \\
\hline MD MANAGEMENT RESERVE FOR DCS OPTION-1 ACTIVITIES & . & & & & $\infty$ & & & $\$ 8,400,000$ & $\$ 8,400,000$ & [D3] \\
\hline "FEE"TO DCS-LLC DURING OPTION 2 & . & & $\$ 12,000,000$ & $\$ 12,000,000$ & oss & & & & $\$ 12,000,000$ & {$[\mathrm{~F} 3]$} \\
\hline TRANSPORTATION OF PUO2 FROM PDCF TO MOX-FFF (N/A) & . & & & & $\infty$ & & & & 0 & \\
\hline \multirow{5}{*}{$\begin{array}{l}\text { TRANSPORTATION OF FRESH FUEL TO REACTOR (SST OPS) } \\
12 \text { YR INCREMENTAL REACTOR OPERATIONS COSTS DUE TO USE OF MOX } \\
\text { COST OF ADDITIONAL ENRICHMENT/ORE (ABOVE ALL LEU) IMPOSED BY MOX FOR CO-RES LEU } \\
\text { INCREMENTAL POOL STORAGEON-SITE STORAGEREPOSITORY COSTS FOR SF }\end{array}$} & . & & & & $\infty$ & & & $\$ 9,700,000$ & $\$ 9,700,000$ & [F4] \\
\hline & * & & $\$ 108,000,000$ & $\$ 108,000,000$ & $\infty$ os & & & & $\$ 108,000,000$ & {$\left[\mathrm{~F}_{3}\right] \mathrm{s}$} \\
\hline & & & & & & & & & & \\
\hline & . & & $\$ 29,600,000$ & $\$ 29,600,000$ & ocs & & & & $\$ 29,600,000$ & \\
\hline & 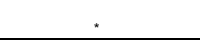 & & & & & & & & & \\
\hline SUBTOTAL & & & $\$ 263,490,207$ & $\$ 263,490,207$ & & $\$ 200,000$ & $\$ 6,300,000$ & $\$ 29,000,000$ & $\$ 298,990,207$ & \\
\hline $\begin{array}{l}\text { EFFECTIVE CREDITS O GOVERNMENT - VALLE OF LEU RELOADS ADJUSTED FOR } \\
\text { DISCOUNT (DOE COSTS ARE AUDIT COSTS) }\end{array}$ & & & $(\$ 574,746,192)$ & $(\$ 574,746,192)$ & & & $\$ 2,000,000$ & $\$ 5,000,000$ & $(\$ 567,746,19$ & [ [2G] \\
\hline
\end{tabular}

TOTAL ESTIMATED PROJECT COST

[] Indicates column/row number of Table 1 subtotal that includes Table 5 entr
$\$ 1,131,516,977$

$\$ 979,839,781$
$\$ 112,438,500$

$182,562,140$

$\$ 1,402,850,979$

\begin{tabular}{|c|c|c|}
\hline & FROM ABOVE & ROUNDED COSTS ${ }^{*}$ \\
\hline SUNK COSTS & $\$ 102,296,000$ & $\$ 100,000,000$ \\
\hline ONGOING DEVELOPMENT & $\$ 126,738,500$ & $\$ 125,000,000$ \\
\hline DESIGN \& CONSTRUCTION OF THE MOX FFF & $\$ 621,351,354$ & $\$ 620,000,000$ \\
\hline OPERATIONS OF THE MOX FFF & $\$ 821,221,109$ & $\$ 820,000,000$ \\
\hline EFFECTIVE VALUE OF FUEL & $(\$ 567,746,192)$ & $\$ 565,000,000$ \\
\hline COST TO CONSTORTUUM REACTORS & $\$ 289,290,207$ & $\$ 290,000,000$ \\
\hline TRANSPORTATION & $\$ 9,700,000$ & $\$ 10,000,000$ \\
\hline TOTAL & $\$ 1,402,850,979$ & $\$ 1,400,000,000$ \\
\hline
\end{tabular}

"Basis of numbers appearing on Table ES-1 of Ref. 7 . 
Table 6. Comparison of 1996 RASR LCCs to those in this study

\begin{tabular}{|c|c|c|c|}
\hline Facility or activity & $\begin{array}{l}1996 \text { RASR cost }{ }^{a} \\
(1996 \text { constant } \$ M)\end{array}$ & $\begin{array}{l}\text { This study }{ }^{a} \\
\text { (2000 constant } \$ M)\end{array}$ & $\begin{array}{l}\text { Explanation of increased cost } \\
\text { (or decreased credit) }\end{array}$ \\
\hline $\begin{array}{l}\text { Fuel qualification (a } \\
\text { reactor-related cost in } \\
\text { RASR) }\end{array}$ & 36 & 120 & $\begin{array}{l}\text { More extensive fuel qualifi- } \\
\text { cation program assumed. }\end{array}$ \\
\hline MOX FFF & 1111 & 1545 & $\begin{array}{l}\text { Aqueous polishing step added } \\
\text { to scope. New building rather } \\
\text { than existing building } \\
\text { (RASR case) assumed. }\end{array}$ \\
\hline $\begin{array}{l}\text { LEU displacement } \\
\text { credit }\end{array}$ & -925 & -568 & $\begin{array}{l}\text { LEU value discounted to } \\
\text { compensate utilities. RASR } \\
\text { cost was not discounted. }\end{array}$ \\
\hline $\begin{array}{l}\text { Modified reactors } \\
\text { (including transpor- } \\
\text { tation of bundles) }\end{array}$ & 528 & 303 & $\begin{array}{l}\text { RASR assumed large irradia- } \\
\text { tion fee based on } \$ 5 \mathrm{M} \text { to } \\
\$ 13 \mathrm{M} \text { per reactor-year. This } \\
\text { report gives incentive to } \\
\text { utilities with discount on } \\
\text { LEU value rather than by } \\
\text { large irradiation fee. }\end{array}$ \\
\hline Total & 750 & 1400 & \\
\hline
\end{tabular}

$a_{\text {Both cases assume 33-MT reactor-based plutonium mission. RASR LCCs formed the basis for the } 1996 \text { TSR }}$ (Ref. 3).

\section{REFERENCES}

1. Record of Decision (ROD) for the Storage and Disposition of Weapons-usable Fissile Materials Final Programmatic EIS, U.S. Department of Energy, January 14, 1997.

2. Plutonium Disposition Life Cycle Costs and Cost-related Comment Resolution Document, DOE/MD-0013, U.S. Department of Energy, November 1999.

3. Technical Summary Report (TSR) for Surplus Weapons-usable Plutonium Disposition, Revision 1; DOE/MD-0003, U.S. Department of Energy, October 31, 1996.

4. S. R. Greene et al., FMDP Reactor Alternative Summary Report (RASR):

Volume 1-Existing LWR Alternative, ORNL/TM-13275/V1, October 1996.

5. Cost Analysis in Support of Site Selection for Surplus Weapons-usable Plutonium Disposition, DOE/MD-0009, U.S. Department of Energy, July 1998.

6. C. Richardson et al., Design-only Conceptual Design Report for the Pit Disassembly and Conversion Facility, and updates LA-13398-MS (December 1997), LA-13486-MS (July 1998), LA-13486-MS (August 1999), Los Alamos National Laboratory.

7. F. Motley, C. Richardson, C. Cliche, and Fluor-Daniel, Inc., Design-only Conceptual Design Report for a Generic Mixed Oxide Fuel Fabrication Facility, LA-13400-MS, Los Alamos National Laboratory, June 1998.

8. Environmental Synopsis Report, U.S. Department of Energy, April 1999.

9. Surplus Plutonium Disposition Final Environmental Impact Statement, DOE/EIS-0283, U.S. Department of Energy, November 1999. 
Page Intentionally Blank 
ORNL/TM-1999-257

\section{INTERNAL DISTRIBUTION}
1. B. B. Bevard
2. S. L. Byerly
3. E. D. Collins
4. B. S. Cowell
5. S. E. Fisher
6. C. W. Forsberg
7. E. C. Fox
8. S. R. Greene
9. R. Holdaway
10. T. Horning
11. J. D. James
12. M. J. Kania
13. S. B. Ludwig
14. G. T. Mays

15. G. E. Michaels

16. R. N. Morris

17. D. L. Moses

18. R. J. Moses

19. R. T. Primm III

20. R. L. Reid

21. D. J. Spellman

22. V. S. White

23. D. L. Williams, Jr.

24-28. K. A. Williams

29. Central Research Library

30. FMDP Library

31. ORNL Laboratory Records (RC)

32-33. ORNL Laboratory Records (OSTI)

\section{EXTERNAL DISTRIBUTION}

34. A. Adami (DOE-CH)

35. D. Alberstein (LANL)

36. J. Baker (DOE HQ/MD-30)

37. D. Bruner (DOE-SR)

38. T. Barr (DOE-CH)

39. A. Caponiti (DOE HQ/MD-30)

40. H. Clark (DOE-OR)

41. R. Elder (DOE-CH)

42. P. Gibson (DOE HQ/MD-5)

43. L. Groves (SNL/DOE-HQ)

44. L. Holgate (DOE HQ/MD-1)

45. M. E. Hassler (NSPO, Y-12)

46. R. Ihde (DCS-Charlotte)

47. J. V. Johnson (DOE HQ/MD-12) 
48. J. Lacy (DOE HQ/MD-40)

49. N. Mote, International Nuclear Consultants, Inc., 415 Mikasa Dr., Alpharetta, GA 30022

50. F. Motley (LANL)

51. D. Nulton (DOE HQ/MD-10)

52. P. T. Rhoads (DOE HQ/MD-12)

53. C. Richardson (LANL)

54. M. Shields (DOE HQ/MD-20)

55. R. Selby (DOE-CH)

56. J. Stevens (Burns \& Roe/DOE-HQ)

57. B. Stevenson (DOE HQ/MD-13)

58. J. H. Thompson (DOE HQ/MD-12)

59. T. Tyborowski (DOE HQ/MD-40)

60. S. Zygmunt (LANL) 